\title{
CONTINUITY AND CHANGE
}

\section{A JOURNAL OF SOCIAL STRUCTURE, LAW AND DEMOGRAPHY IN PAST SOCIETIES}

\author{
VOLUME 24 PART 2 AUGUST 2009
}

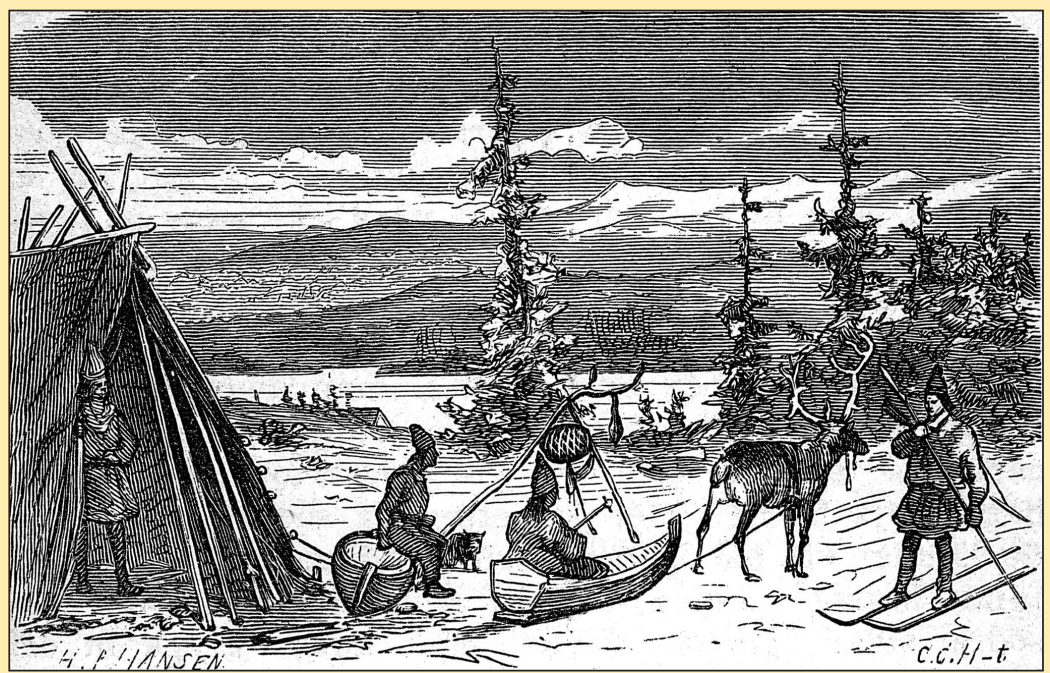


A journal of social structure, law and demography in past societies

\author{
EDITORS \\ LLOYD BONFIELD, New York Law School \\ MARY LOUISE NAGATA, Francis Marion University \\ PHILLIPP R. SCHOFIELD, Aberystwyth University \\ RICHARD WALL, University of Essex \\ ASSOCIATE EDITORS \\ FELICE BATLAN, Chicago-Kent College of Law \\ ELIZABETH BRIGHT JONES, Colorado State University \\ TRACY DENNISON, California Institute of Technology \\ EILIDH GARRETT, Sheffield \\ JULIE MARFANY, University of Cambridge \\ BOOK REVIEW EDITOR \\ FELICE BATLAN, Chicago-Kent College of Law \\ PRODUCTION MANAGER \\ BEATRICE MORING, Cambridge, UK
}

EDITORIAL ASSISTANT AND EDITORIAL OFFICE

Belinda WATERman, University of Essex, Wivenhoe Park Colchester CO4 3SQ

EDITORIAL BOARD

M. BOURIN, University of Paris, France

A. FAuve, Ecole des Hautes Etudes, Paris

E. FOYSTER, University of Cambridge, UK

A. FURIO, University of Valencia, Spain

s. HOCH, University of Kentucky, USA

S. KUROSO, Reitaku University, Japan

E. PURCELL, New York Law School, USA

C. SARASUA, Universitat Autònoma de Barcelona, Spain

\author{
M. SCHROVER, Leiden University, \\ The Netherlands \\ R. SMITH, University of Cambridge, UK \\ T. SOKOL, Fern University Hagen, \\ Germany \\ E. THOEN, Gent University, Belgium \\ F. TOWERS, University of Calgary, Canada \\ J. L. VAN ZANDEN, Utrecht University, \\ The Netherlands
}

\title{
SUBSCRIPTIONS
}

Continuity and Change (ISSN 0268-4160) is published in volumes of three parts. The subscription price (excluding VAT) of volume 24, 2009, which includes print and electronic access, is $£ 174$ (US \$298) for institutions; $£ 50$ (US \$84) for individuals, which includes print only, ordering direct from the Press and certifying that the journal is for their personal use. The electronic-only price available to institutional subscribers is $£ 152$ (US \$259). Single parts cost $£ 58$ (US \$101) plus postage. US dollar prices apply to the USA, Canada and Mexico. EU subscribers (outside the UK) who are not registered for VAT should add VAT at their country's rate. VAT registered subscribers should provide their VAT registration number. Orders, which must be accompanied by payment, may be sent to a bookseller, subscription agent or direct to the publishers: Cambridge University Press, The Edinburgh Building, Shaftesbury Road, Cambridge CB2 8RU. Orders from the USA, Canada and Mexico should be sent to Cambridge University Press, Journals Fulfillment Department, 100 Brook Hill Drive, West Nyack, New York 10994-2133. Japanese prices for institutions are available from Kinokuniya Company Ltd, P.O. Box 55, Chitose, Tokyo 156, Japan. Prices include delivery by air.

This journal is included in the Cambridge Journals Online service which can be found at http://journals.cambridge.org/. For further information on other Press titles access http://www.cambridge.org/.

\section{COPYING}

This journal is registered with the Copyright Clearance Center, 222 Rosewood Drive, Danvers, MA 01923, USA. Organizations in the USA who are also registered with C.C.C. may therefore copy material (beyond the limits permitted by sections 107 and 108 of US copyright law) subject to payment to C.C.C. of the per copy fee of $\$ 15$. This consent does not extend to multiple copying for promotional or commercial purposes. Code 0268-4160/2009 \$15. Organizations authorized by the Copyright Licensing Agency may also copy material subject to the usual conditions. 


\section{Contents}

\section{CONTINUITY AND CHANGE 24:2}

\section{A RTICLES}

BJøRG EVJEN AND LARS IVAR HANSEN One people-many names: on different designations for the Sami population in the Norwegian county of Nordland through the centuries

STEPHEN MATTHEWS Money supply and credit in rural Cheshire, c. $1600-$ c. 1680

ilja VAn Damme And Reinoud Vermoesen Second-hand consumption as a way of life: public auctions in the surroundings of Alost in the late eighteenth century

DAVID R. GREEN, ALASTAIR OWENS, JOSEPHINE MALTBY AND JANETTE RUTTERFORD Lives in the balance? Gender, age and assets in late-nineteenth-century England and Wales

MARY CLAYTON Changes in Old Bailey trials for the murder of newborn babies, 1674-1803

ORNA ALYAGON DARR The devil's mark: a socio-cultural analysis of physical evidence

\section{BOOK REVIEWS}

MAYA SHATZMILLER, Her day in court: women's property rights in fifteenth-century Granada. Reviewed by Marie-Pierre Arrizabalaga CHRISTOPHER W. BROOKS, Law, politics and society in early modern England.

Front cover illustration: 'I Lappland' by H.P. Hansen in Topelius, Z. Visor och Sagor, Lasning för barn, Andra Boken, Stockholm 1904, Albert Bonnier 